\title{
INSTITUTIONAL FACTORS OF ECONOMIC PERFORMANCE: EVIDENCE FROM THE WORLD VALUE SURVEY
}

\author{
Andriy Maksymuk ${ }^{1}$, Nataliya Kuzenko²
}

\begin{abstract}
This article highlights the impact of values on the country's welfare. Values that are quite constant over a long period of time form an institutional framework within the country. They can contribute to economic development or even prevent it. The aim of the article is to explore, what is the influence of social values, democracy and trade on welfare levels in different counties. The hypothesis is that the dominance in society of secular-rational values and the values of self-expression, democracy and trade (openness to the world) have a positive effect on the level of welfare of countries. The empirical part of the paper is based on the comparative analysis of relationship between GDP per capita and four values such as tolerance and respect, obedience, trust and freedom of choice for two waves of WVS - 2005-2009 and 2010-2014. Using correlation and regression analysis, the relationships between these indicators were evaluated. These values have a positive impact on welfare in OECD countries, some countries of Latin America, Asia and Africa with middle income per capita. However, there is a negative relationship between obedience and GDP per capita. This value is more important for some African and Asian countries and India. The relationship between GDP per capita and the aggregate value index showed a strong positive correlation for OECD countries. Then the regression model was estimated to assess the impact of values, trade and level of democracy on welfare growth and development. The results of the regression analysis showed a significant effect of the aggregated value indicator for all six samples, but this effect is weaker for high-income countries. The effect of the level of democracy is significant and positive only for the sub-sample of democratic countries, while it is negative for high-income countries. The effect of the level of trade on GDP per capita is statistically significant for the sample of all countries, the sub-sample of non-democratic countries and the sub-sample of high income and upper-middle income countries. Thus, we conclude that the institutional factors (the values and the level of democracy) are important determinants of GDP per capita for democratic countries while for non-democratic countries trade is more important.
\end{abstract}

Key words: social values, formal and informal institutions, GDP per capita, trade, democracy.

JEL Classification: A13

\section{Introduction}

The difference of economic development in the world encourages scientists and researchers to find answers to the question of why the level of welfare in some countries is high, and in others, on the contrary, is low. There is a need for interdisciplinary researches that take into account not only quantitative economic factors but also other formal and informal institutional factors.

In this paper, our focus is on the relationship between informal institutions and economic development. Values that are quite constant over a long period of time form an institutional framework within the country.

\footnotetext{
Corresponding author:

${ }^{1}$ Ivan Franko National University of Lviv, Ukraine.

E-mail: andriy.maksymuk@lnu.edu.ua

ORCID: https://orcid.org/0000-0002-5119-0380

${ }^{2}$ Ivan Franko National University of Lviv, Ukraine.

E-mail: nataliya.kuzenko@lnu.edu.ua

ORCID: https://orcid.org/0000-0003-4935-8102
}

However, globalization affects social processes in countries, the reaction and perception / non-perception of society of certain value categories. This, in turn, can affect government policy and economic well-being. Values can contribute to economic development or even can prevent it.

We assume that level of democracy and trade (openness level) as well as system of values (tolerance and respect for other people, trust, freedom of choice and obedience) has impact on GDP income level. The higher the level of secular-rational and self-expression values, the level of democracy and trade (openness), the higher GDP level is. It is our hypothesis we are going to test in this paper. 
Based on G. Tabellini' approach (Tabellini, 2005), we constructed an aggregate value index that include four indicators - tolerance and respect, obedience, trust and freedom of choice. According to Inglehart-Welzel cultural map (Inglehart and Welzel, 2020), values like that describe culture of country. Depending on what values prevail in society, it can be assumed what value system dominates in a country - traditional or secular; survival or self-expression. This allows us to analyse whether the propensity for conservative views and materialistic values (survival values) really contribute to economic well-being or vice versa.

Comparative analysis of relationship between GDP per capita and four values such as tolerance and respect, obedience, trust and freedom of choice for two waves - 2005-2009 and 2010-2014 - allowed us to make certain assumptions about the importance and impact of values on the level of well-being. There is a positive relationship between GDP per capita tolerance and respect, trust and freedom of choice. These values are likely to have a positive impact on welfare in OECD countries, some countries of Latin America, Asia and Africa with middle income per capita and up as they are above the trend line. For other countries (with some development troubles) these values are not so important. However, there is a negative relationship between obedience and GDP per capita. This value is more important for some African and Asian countries, and India.

Correlation analysis of the relationship between GDP per capita and the aggregate value index allowed to determine the nature of this relationship and more clearly classify the countries where these values play an important role and, accordingly, contribute to economic development. There is a strong positive correlation for OECD countries.

Afterwards we add two more variables in the analysis - the democracy index and trade which shows the country's openness to the world. Also these variables are the criteria for dividing our counties for samples.

We built regression model to evaluate the influence of values, trade and level of democracy on welfare growth and development. There is a significant effect of the aggregated value indicator for all six samples (depends on income and democracy level), but the effect is weaker for high-income countries. The coefficient for the level of democracy is significant and positive only for the sub-sample of democratic countries, while it is negative for the high-income countries. The effect of the level of trade on GDP per capita is statistically significant for the sample of all countries, the sub-sample of nondemocratic countries and the sub-sample of high income and upper-middle income countries.

We conclude that the institutional factors (the values and the level of democracy) are important determinants of GDP per capita for democratic countries while for non-democratic countries trade is more important.

\section{Literature review}

The starting point of our study is the InglehartWelzel cultural map (Inglehart and Welzel, 2020). This map illustrates two main dimensions of intercultural variation: traditional values versus secular values, and survival values versus self-expression values.

Traditional values emphasize the importance of religion, parent-child ties, deference to authority and traditional family values. People who embrace these values also reject divorce, abortion, euthanasia, and suicide. These societies have high levels of national pride and a nationalistic outlook.

Secular-rational values have the opposite preferences to the traditional values. These societies place less emphasis on religion, traditional family values and authority. Divorce, abortion, euthanasia, and suicide are seen as relatively acceptable (Suicide is not necessarily more common).

Survival values place emphasis on economic and physical security. It is linked with a relatively ethnocentric outlook and low levels of trust and tolerance.

Self-expression values give high priority to environmental protection, growing tolerance of foreigners, gays and lesbians, and gender equality, and rising demands for participation in decision-making in economic and political life (Inglehart and Welzel, 2020).

On the development path values of self-expression become more important than values of survival. Changing the position of the country on the map diagonally from the bottom up means development. According to Inglehart and Welzel (Inglehart, Welzel, 2005), the greatest changes in society's value system occur on the stage of transition from an agrarian to an industrial economy. And at the stage of transition from an industrial society to a knowledge society, the role of individualism increases. Therefore, the values of survival change towards the values of self-expression.

Hence, we assume that such values as tolerance and respect for other people, trust and freedom of choice have a positive impact on income level; obedience has a negative influence. Moreover, we investigate the influence of values among such factors as trade and democracy regime on GDP per capita level. The idea is to find out whether the influence of values is the same for democratic and authoritarian regimes.

The theoretical and methodological basis of our study are the works of such authors as R. Inglehart and C. Welzel (Inglehart, Welzel, 2005), G. Tabellini (Tabellini, 2005), S. Knowles and C. Weatherston (Knowles, Weatherston, 2006), C. Dobler (Dobler, 2011), D. Pyrkosz (Pyrkosz, 2017), G. Amoranto, N. Chun, and A. Deolalikar (Amoranto, Chun, Deolalikar, 2010) and others.

C. Dobler (Dobler, 2011) in her work investigates the impact of formal and informal institutions on 
economic growth in the Middle East and North Africa. The author attributes trust, limited and generalized morality and dignity, and life after death to informal institutions. The author defines beliefs as accumulating of physical and human capital. C. Dobler refers to formal institutions: property rights; legal system - the rule of law, form of government - democracy.

C. Dobler concludes: "Regarding informal institutions, the evaluation of WVS data indicated a societal structure of limited morality in the MENA region. The results regarding trust and control are not that obvious; however, respect and obedience indicate a hierarchical society with an emphasis on collective and hierarchic structures. In addition, the analysis of further survey questions showed a traditional attitude regarding the roles of women, education, work, and family in general" (Dobler, 2011).

D. Pyrkosz (Pyrkosz, 2017) studies the cultural determinants of economic development of Poland and Ukraine in the period 1990-2014. This research is also based on WVS data. The author emphasizes that values are an important factor in economic development, and common values between countries strengthen their interaction and provide comparative advantages. The author believes that Poland needs to develop rational values, and Ukraine should develop the values of selfexpression.

G. Amoranto, N. Chun, and A. Deolilakar (Amoranto, Chun, Deolalikar, 2010) explore the relationship between class status and more progressive values. The study is based on the World Values Survey (WVS) data and covers the period 1996-2008 for different countries. The authors associate the middle class not only with parameters such as consumption or income, but also with higher education, more skilled and stable jobs and the ability to "save".

The authors formed six groups of values that contribute to greater economic growth and prosperity: market competition, increased mobility, trust, gender equality, the value of science and technology, and political activism. They believe that the middle class plays a greater role in political activity compared to the poor and upper classes, so the middle class is especially important in the development of society, because it requires greater political responsibility.

In all these works, values are an important factor in economic and institutional development, which indicates the relevance of this study. Despite the fact that the issue of values is covered in many works, there is still a need for further research, as the world is constantly changing and economic development is rather a dynamic process.

\section{Methodology}

The methodology of our study is based on papers of G. Tabellini (Tabellini, 2005), S. Knowles and
C. Weatherston (Knowles, Weatherston, 2006). Later, this approach was used by C. Dobler (Dobler, 2011). Using World Value Survey (WVS) data, G. Tabellini (Tabellini, 2005) developed an aggregated index of four cultural values: trust, control, respect, and obedience.

We also used these values, but over different time period, for different sample of countries and on the basis of different indicators (questions) of WVS:

1. Tolerance and respect for other people (percentage of people that consider it especially important that a child learns tolerance and respect for other people at home).

2. Obedience (percentage of people that consider it especially important that a child learns obedience at home). This factor does not promote growth. According to G. Tabellini, obedience is a typical characteristic of hierarchical societies where individuality is suppressed and obedience is more important than personal opinion and responsibility. Suppression of individuality makes co-operation difficult and affects economic growth negatively.

3. Trust in people you meet for the first time (proportion of people reporting that people you meet for the first time can be completely or somewhat trusted). According to G. Tabellini, high level of trust decreases transaction costs, thus increasing the number of transactions and promoting economic growth.

4. Freedom of choice and control (10-point scale, where 10 means "a great deal of choice" to indicate how much freedom of choice and control you feel you have over the way your life turns out). We believe that the more control you feel you have over the way your life turns out, the higher output you produce.

Similarly to G. Tabellini, we calculated an aggregated value indicator, using the following formula:

$$
\begin{aligned}
& \text { Aggregated_indicator }=\text { tolerance\&respect- } \\
& \text { obedience }+ \text { trust }+10^{*} \text { choice \&control }
\end{aligned}
$$

The indicator of freedom of choice and control, based on the 10-point scale, was multiplied by 10 , in order to convert it to the 100-point scale (like other indicators). The indicator of obedience that is expected to show negative relationship with GDP per capita has a minus sign in this formula.

This aggregate index allows us to assess the relationship between welfare and values and then using regression analysis to model the impact of the aggregate value index, democracy and trade on GDP per capita.

\section{Empirical results and discussion}

The empirical part of the paper is built on the comparative analysis of relationship between GDP per capita and four values such as tolerance and respect, obedience, trust and freedom of choice for two waves - 
2005-2009 ${ }^{1}$ and $2010-2014^{2}$. Then we build regression model to assess the impact of values, trade and level of democracy on welfare growth and development.

Figure 1 shows relationship between tolerance and respect for other people and GDP per capita in studied countries. We have calculated logarithms of average GDP per capita over 2005-2009 for each country using the World Bank data ${ }^{3}$. We believe that the more a country deviates from traditional values, the higher its level of wellbeing is compared to other countries.

African and Asian countries are generally located in the bottom left corner, what means that they do not pay enough attention to this value and have comparatively low GDP per capita. OECD countries are located in the top right corner, what means that they have comparatively high GDP per capita and pay much attention to tolerance and respect for other people. Ukraine is located above the trend line, thus Ukrainians do not pay enough attention to this value, and percentage is one of the smallest in the world.
Since several countries were covered by both waves, it is worth analysing how their value orientations have changed. Percentage of people that consider it especially important that a child learns tolerance and respect for other people at home decreases in South Africa (-25.4 percentage points), South Korea (-16.1), Argentina (-13.3), and China (-12.5). Meanwhile, the percentage increases in India $(+33.5)$, Thailand $(+6.7)$, Romania (+6.6), and Slovenia (+6.2). A slight increase is also recorded in Ukraine $(+2.9)$. In general, data from the last wave show weaker relationship between this indicator and GDP per capita (Figure 2). Ukraine moves below the trend line, what means that this value becomes more important for Ukraine, than the world's average level for countries with comparable levels of GDP per capita. Ukraine is located on the graph near Armenia, Nigeria, Morocco and Tunisia.

Negative relationship is found between GDP per capita and percentage of people that consider it especially important that a child learns obedience

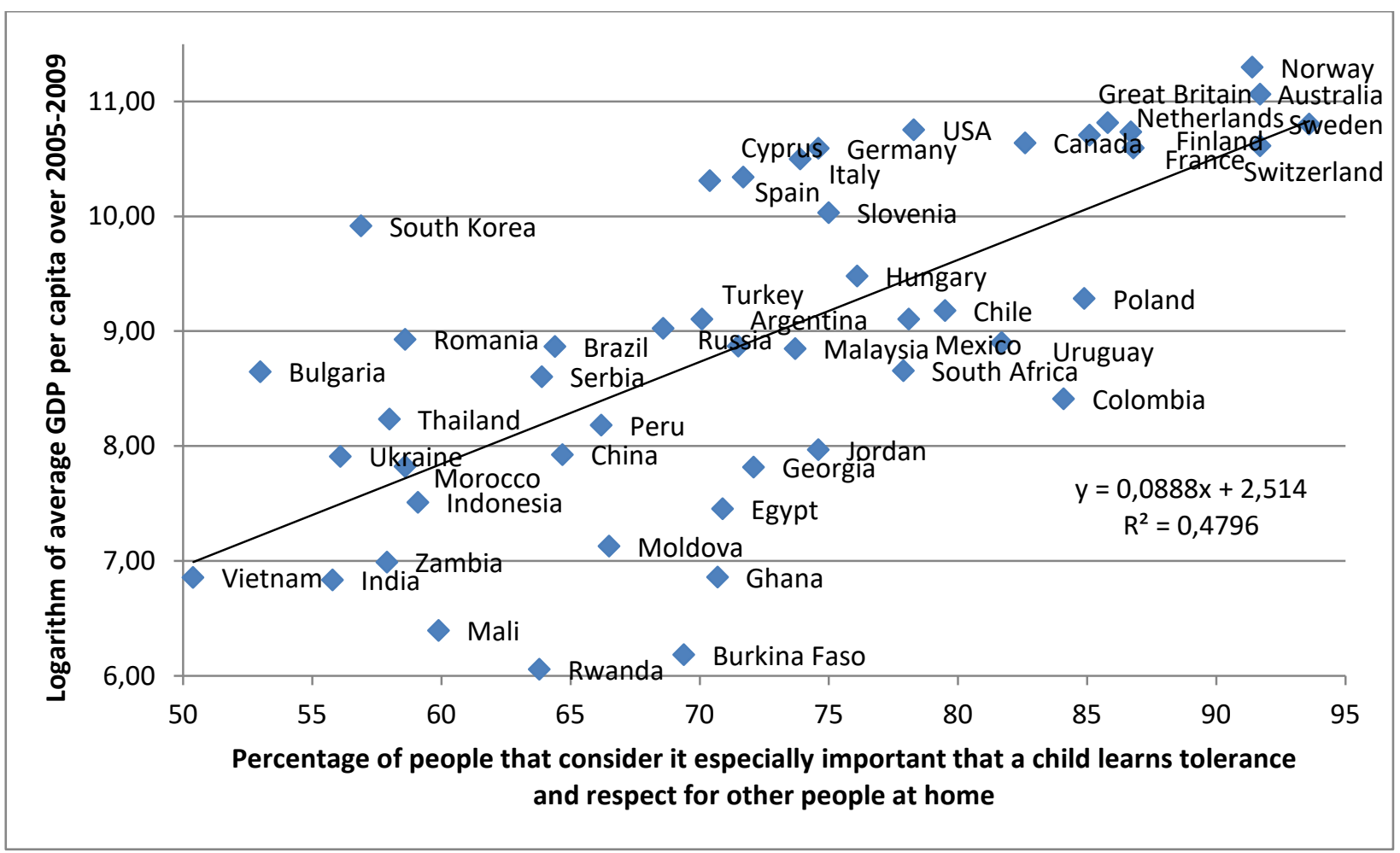

Figure 1. Relationship between GDP per capita and tolerance and respect, 2005-2009

\footnotetext{
${ }^{1}$ The wave 5 of 2005-2009 covers 48 countries: Argentina, Australia, Brazil, Bulgaria, Canada, Chile, China, Colombia, Cyprus, Finland, France, Georgia, Germany, Ghana, Hungary, India, Indonesia, Italy, Jordan, South Korea, Malaysia, Mali, Mexico, Moldova, Morocco, Netherlands, Norway. Peru, Poland, Romania, Russia, Rwanda, Serbia, Vietnam, Slovenia, South Africa, Spain, Sweden, Switherland, Thailand, Turkey, Ukraine, Egypt, Great Britain, USA, Burkina Faso, Uruguay and Zambia.

${ }^{2}$ The wave 6 (2010-2014) covered 54 countries: Australia, Chile, Cyprus, Estonia, Germany, Japan, South Korea, Kuwait, Netherlands, Poland, Qatar, Singapore, Slovenia, Spain, Sweden, USA, Uruguay, Algeria, Azerbaijan, Argentina, Armenia, Brazil, Belarus, China, Colombia, Ecuador, Georgia, Iraq, Kazakhstan, Jordan, Lebanon, Libya, Malaysia, Mexico, Peru, Romania, Russia, South Africa, Thailand, Turkey, Ghana, Haiti, India, Kyrgyzstan, Morocco, Nigeria, Pakistan, Philippines, Rwanda, Zimbabwe, Tunisia, Ukraine, Egypt, and Uzbekistan.

${ }^{3}$ World Development Indicators, 2020. GDP Per Capita (Current US\$) | World Bank DataBank. [online] Available at: https://data.worldbank. org/indicator/NY.GDP.PCAP.CD (accessed 30 April 2020)
} 


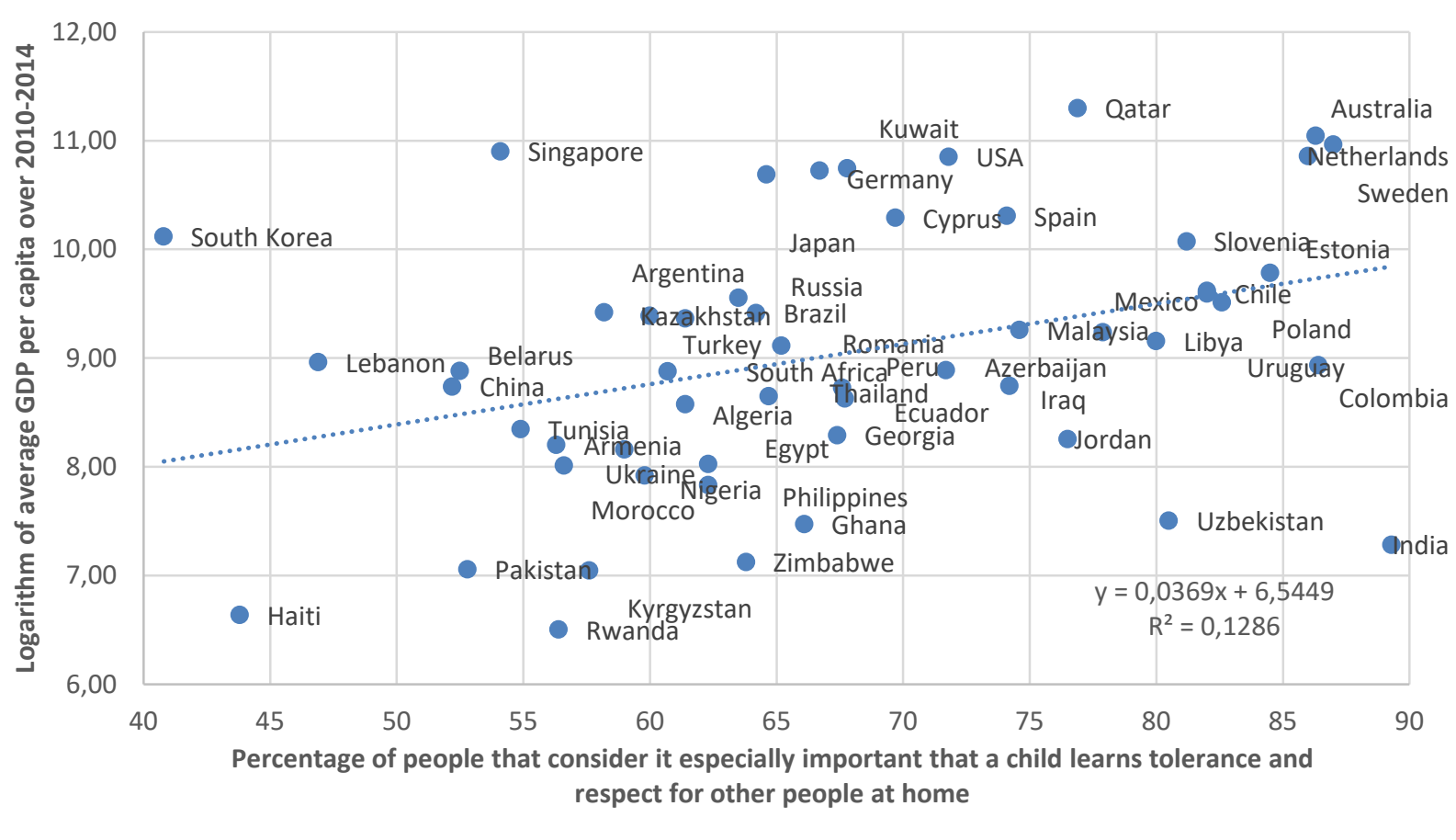

Figure 2. Relationship between GDP per capita and tolerance and respect, 2010-2014

at home. OECD countries are located in the top left corner, while African countries are located in the bottom right corner (Figure 3). Many communist or post-socialist countries are located in the bottom left corner, what means that people in these countries do not consider obedience to be important, but the GDP per capita in these countries is much lower than the one in most developed countries. Ukraine is also

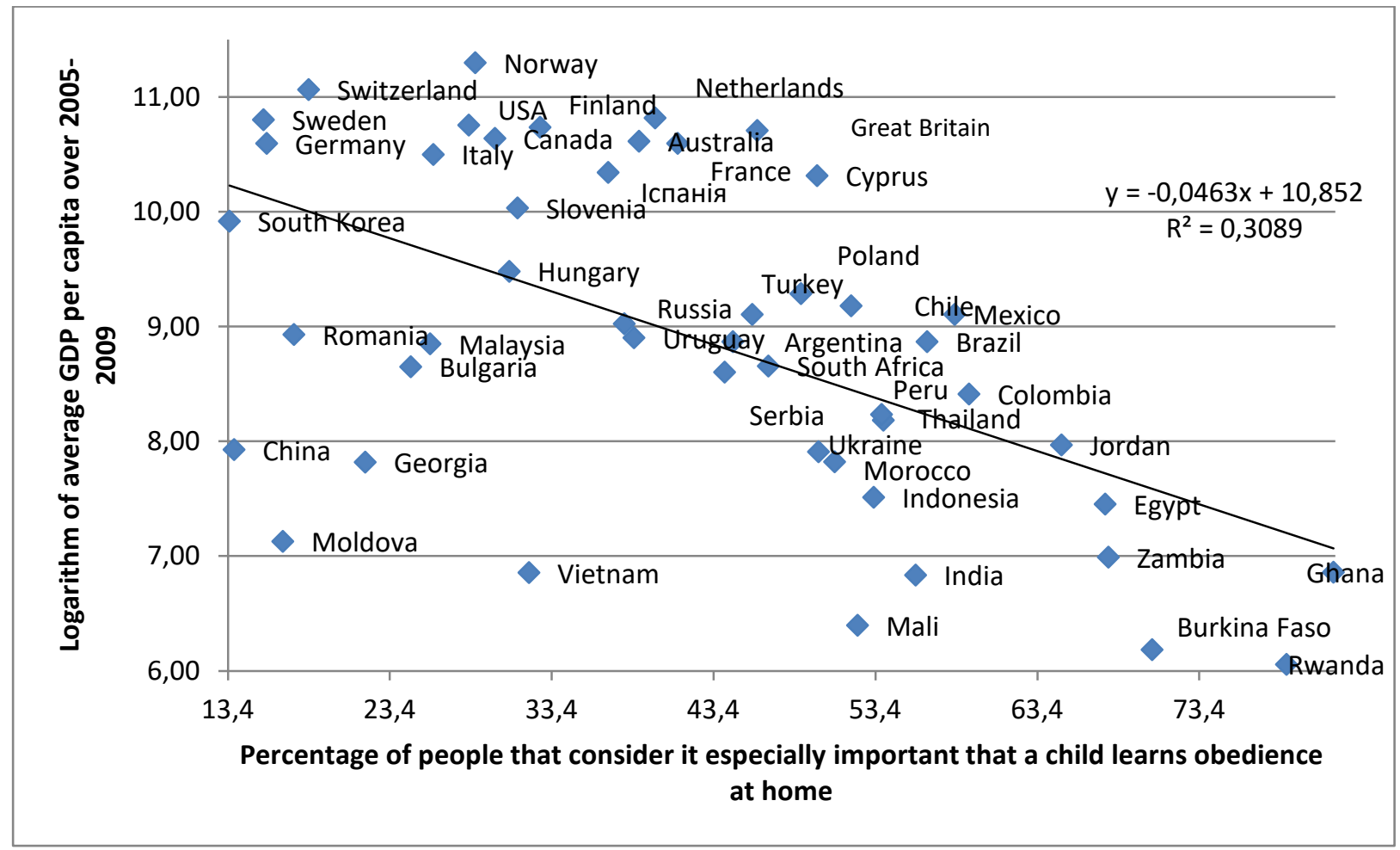

Figure 3. Relationship between GDP per capita and obedience, 2005-2009 


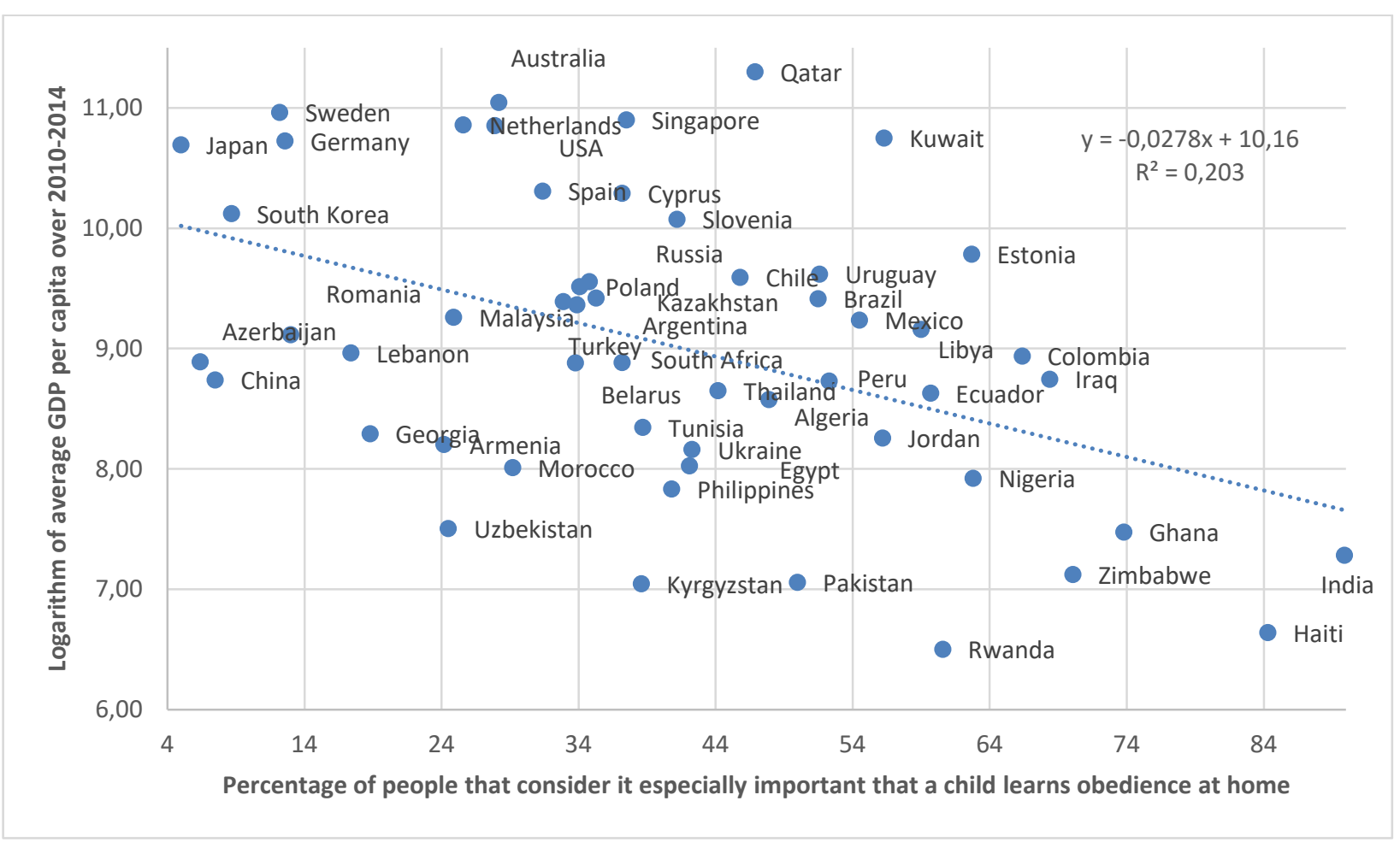

Figure 4. Relationship between GDP per capita and obedience, 2010-2014

located below the trend line, what means that people do not consider obedience very important compared to some Asian, African and Latin American countries.

Compared to the previous wave, the relationship between the obedience and GDP per capita also becomes weaker, but negative relationship persists (Figure 4). Having analysed dynamics of this indicator, we have found that the highest growth is recorded in India ( +34 percentage points), and Uruguay (+13.1), while the highest decrease is recorded in Egypt (-25.5), Morocco (-21.7), and Rwanda (-18.2). In Ukraine, the obedience also becomes less important, compared to the previous wave ( -7.6 percentage points).

The relationship between the level of trust and GDP per capita is positive (Figure 5). OECD countries are located in the top right corner, while African, Asian, South American and former USSR countries (including Ukraine) are located in the bottom left corner, what means that the level of trust in other people is low in these countries. It is worth mentioning that the poorest African countries (Mali, Burkina Faso, and Rwanda) report average levels of trust and even higher than in some EU countries.

For the trust in people you meet for the first time, the highest growth is found for Chile $(+10.4$ percentage points), South Africa (+9.4), and Ukraine (+9.1), while the highest decrease is found for Sweden $(-11.2)$, Uruguay (-8.6), and Ghana (-7.3). In 2010-2014, the relationship between the level of trust and GDP per capita becomes weaker (Figure 6). In Ukraine, both the level of GDP per capita and the level of trust increase.

The relationship between the perception of freedom of choice and control and GDP per capita is also positive (Figure 7). African and post-socialist countries (including Ukraine, with one of the lowest scores) are located in the bottom left corner. OECD countries (somewhat higher) and Latin American countries (somewhat lower) are located in the top right corner. Some countries are located in the bottom right corner, which means that their perception of freedom of choice and control is high, but their GDP per capita is not high enough (Asian, African countries and Moldova). However, the countries with the low level of the perception of freedom of choice and control, but high level of GDP per capita are located in the top left corner: Italy, Poland, Hungary, and the Netherlands. Concerning the perception of freedom of choice and control, the largest decrease in comparison to the previous has been recorded in Russia (-1.08), Argentina (-0.53), South Africa (-0.49), and Jordan (-0.37). The largest growth of this indicator is recorded in Morocco $(+0.88)$, Thailand $(+0.61)$, Ukraine $(+0.54)$, and Slovenia $(+0.39)$.

Compared to the previous wave, the relationship between this indicator and GDP per capita has become weaker (Figure 8). Ukraine is again below the trend line near other post-socialist and North African countries. Countries with high GDP per capita and high level of perception of freedom of choice and control are located in the top right corner (Qatar, Kuwait, Australia, 


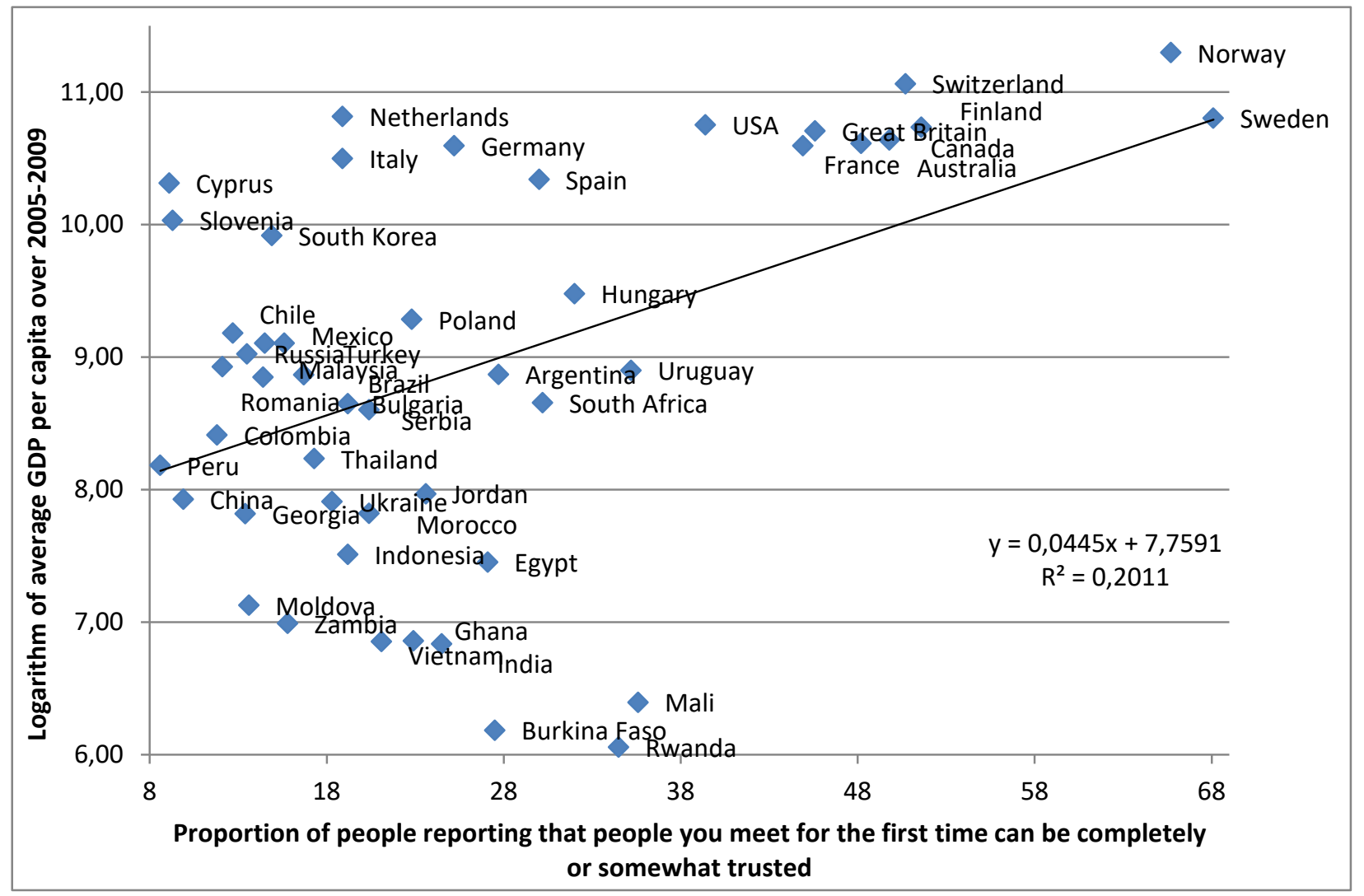

Figure 5. Relationship between GDP per capita and trust, 2005-2009

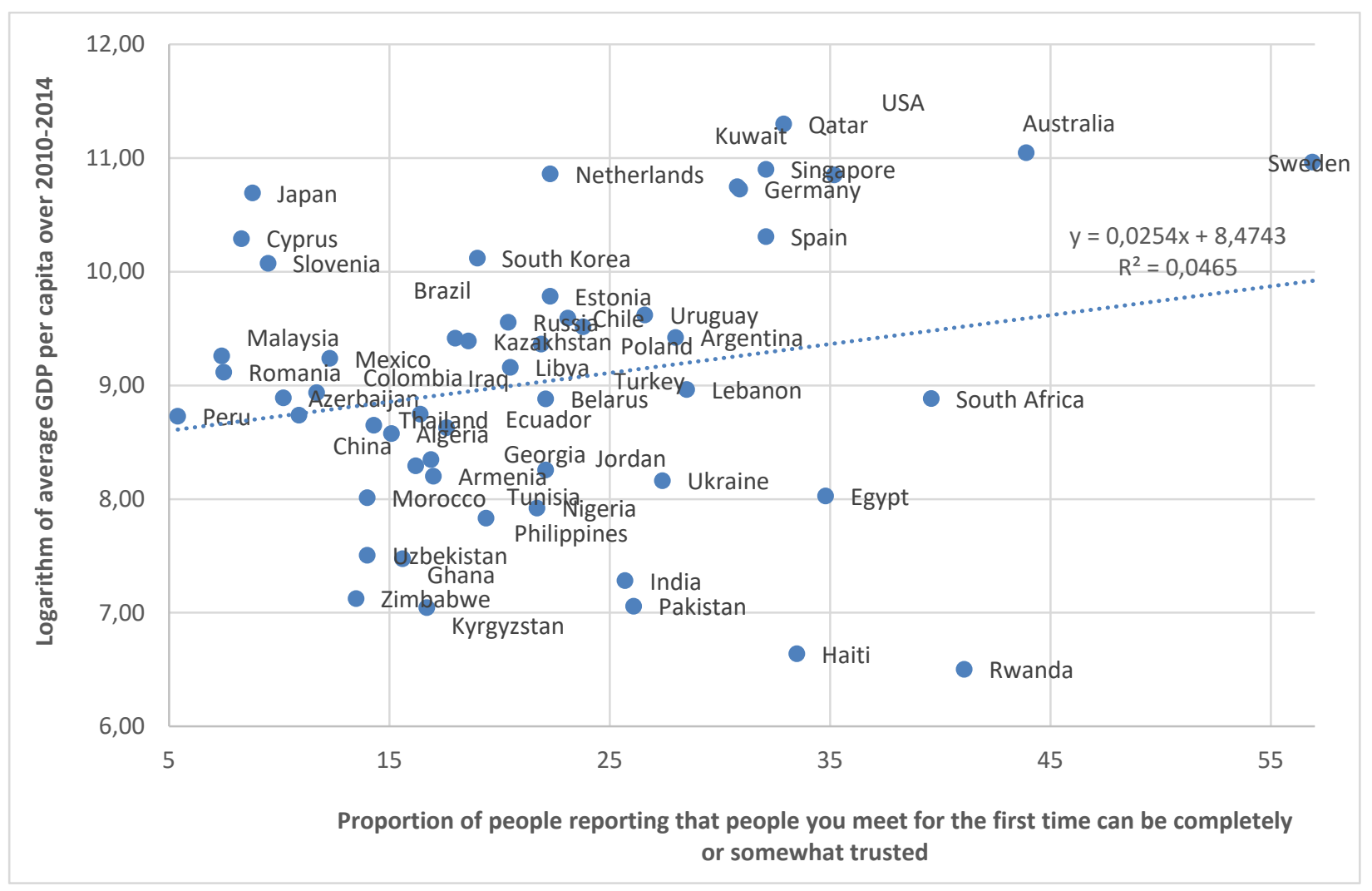

Figure 6. Relationship between GDP per capita and trust, 2010-2014 


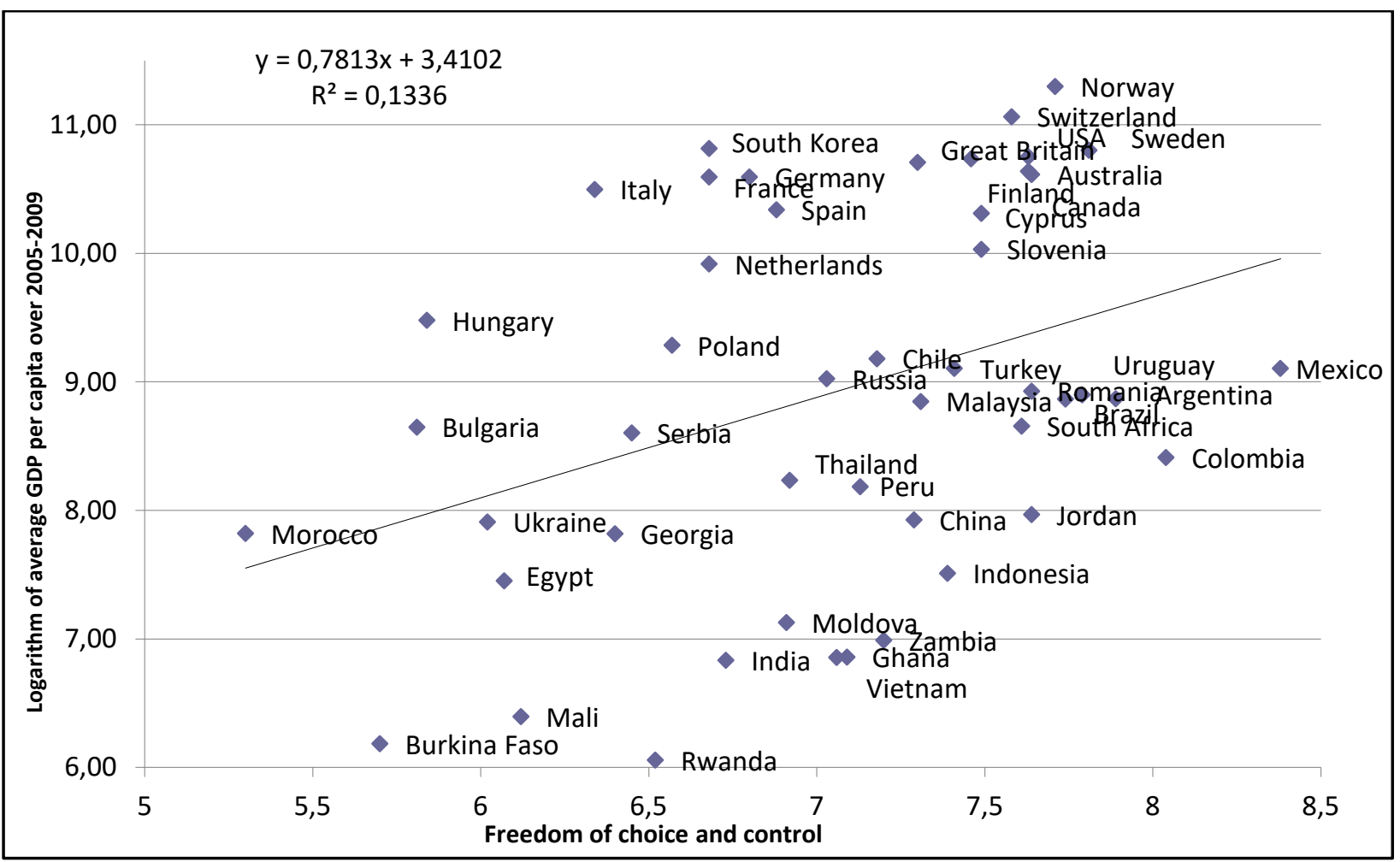

Figure 7. Relationship between GDP per capita and choice and control, 2005-2009

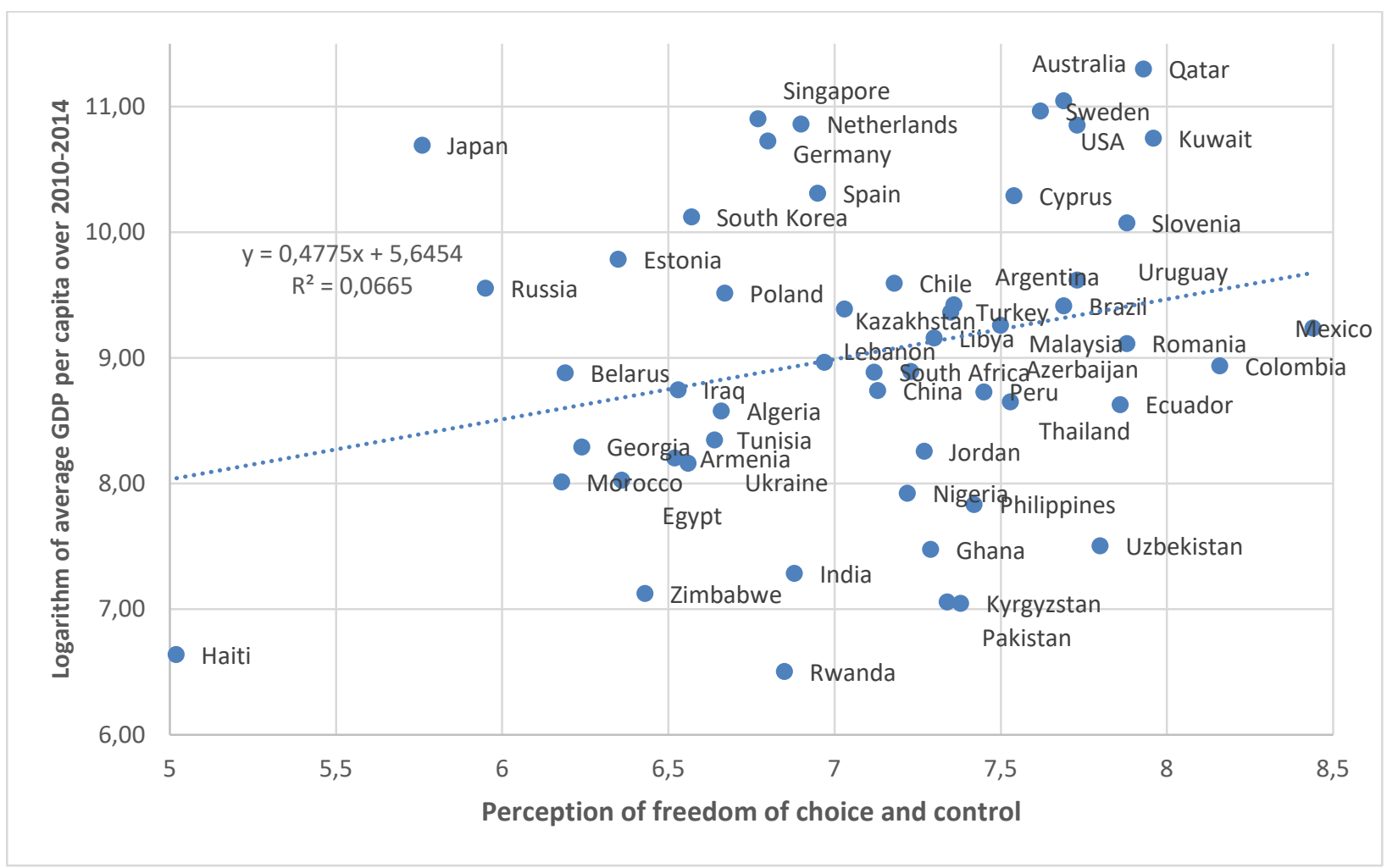

Figure 8. Relationship between GDP per capita and choice and control, 2010-2014 


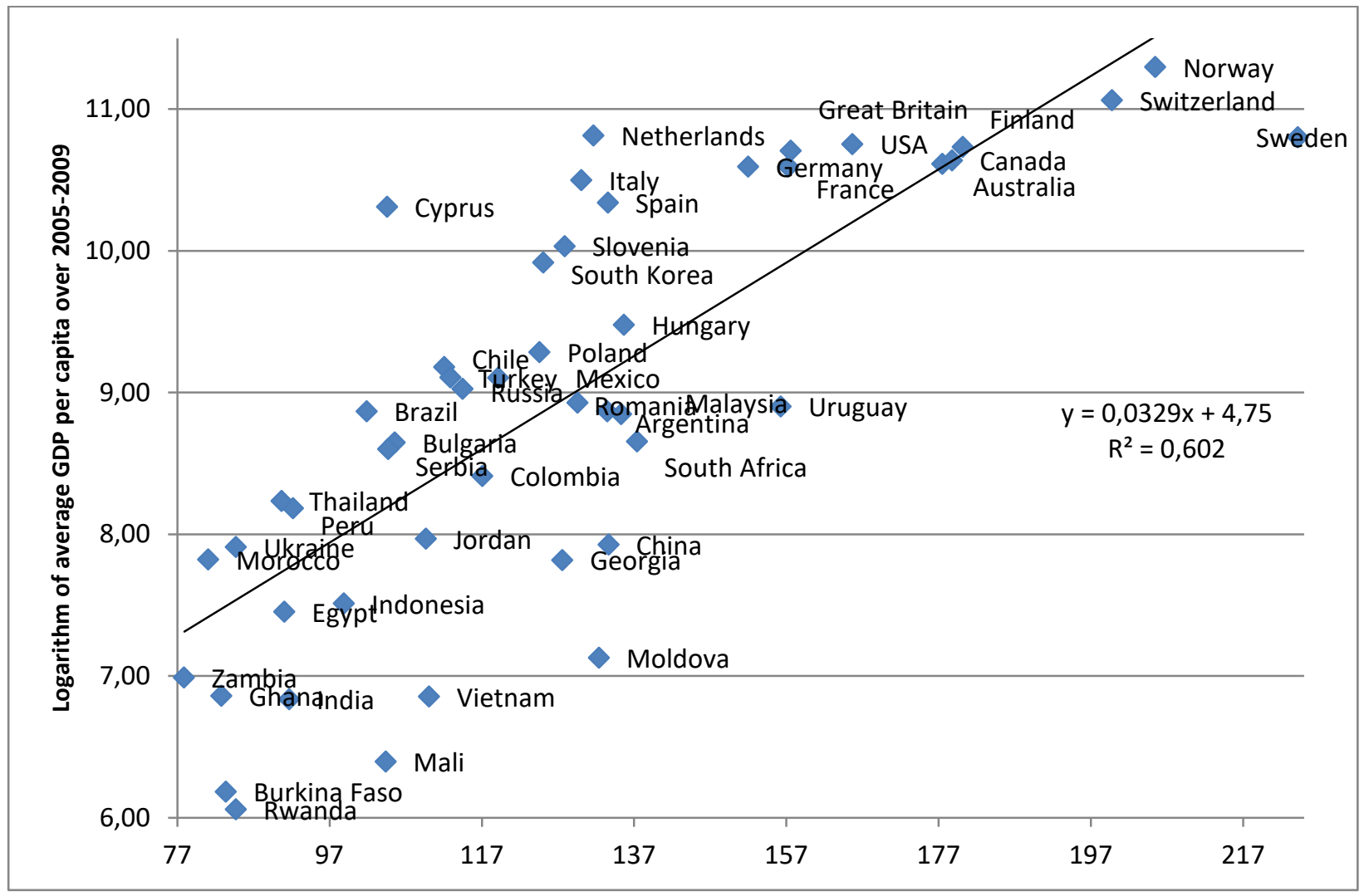

Figure 9. Relationship between GDP per capita and the aggregated value indicator, 2005-2009

the USA, and Sweden). Countries with high level of perception of freedom of choice and control, but low level of GDP per capita are located in the bottom right corner (Uzbekistan, Kyrgyzstan, and Pakistan).

The relationship between GDP per capita and the aggregated value indicator is positive (Figure 9). $\mathrm{R}$-squared is higher than for every separate component of the aggregated indicator. OECD countries are located in the top right corner, while African, Asian countries, and Ukraine are located in the bottom left corner.

The relationship between GDP per capita and the aggregated value indicator is also weaker for the new wave, than for the previous one, but stronger, than for each component value, what confirms that the calculation formula of this indicator is suitable for analysis of the effect of values on GDP per capita. Compared to the previous wave, the largest growth of this indicator was recorded in Egypt $(+27.5)$, Ukraine (+25), Morocco (+22.1), and Rwanda $(+20.7)$, while the largest decrease was recorded in Uruguay (-22). Despite the growth of GDP per capita, Ukraine moved below the trend line, due to the considerable improvement of the aggregated value indicator (Figure 10).
Further, we studied the relationship between GDP per capita and the level of democracy (formal institutions), using data of the Center for Systemic Peace ${ }^{4}$, ranging from -10 (Autocracy) to +10 (Full democracy). The relationship between the level democracy and GDP per capita is positive (Figure 11). OECD countries are located in the top right corner, Asian and African countries - in the bottom left corner. Relatively democratic countries with low level of GDP per capita, in particular, African, Asian countries and Moldova, are located in the bottom right corner. Ukraine is also located below the trend line and is one of the most democratic countries with comparable level of GDP per capita.

The relationship between the level of democracy and GDP per capita also became weaker, compared to the previous period (Figure 12). The highest progress in the development of democratic institutions was observed in Malaysia ( +3 points), Egypt, Ghana, Turkey, and Morocco (both +2 points), a certain regress was observed in Russia, Thailand (both -2 points), and Jordan (-1 point). In Ukraine, the level of democracy did not change, compared to the previous period. OECD countries are located in the top right corner, African countries, China and some

\footnotetext{
${ }^{4}$ Polity IV Project: Polity IV Individual Country Regime Trends, 1946-2013. Available at: http://www.systemicpeace.org/polity/polity4x.htm (accessed 30 April 2020)
} 


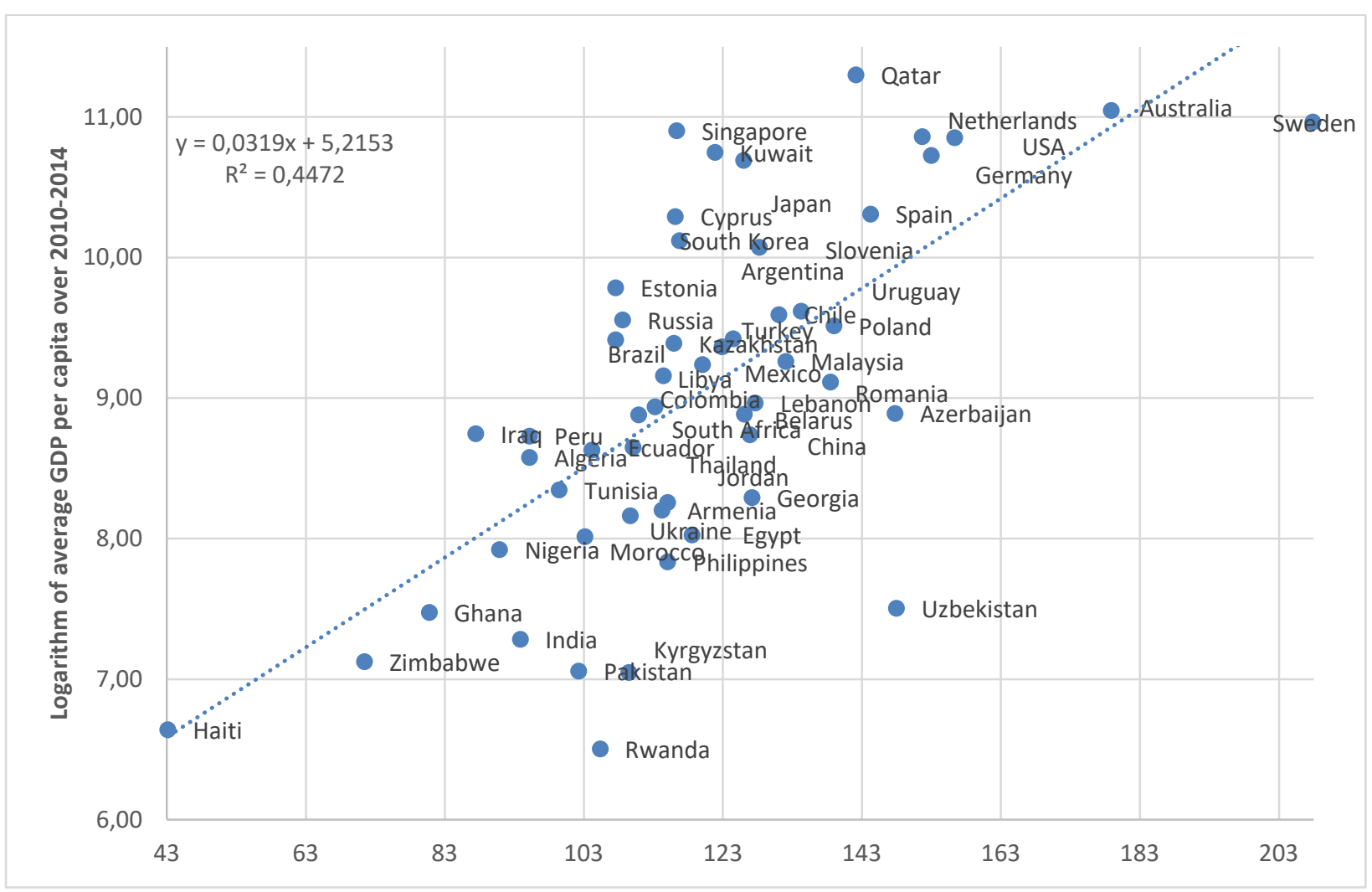

Figure 10. Relationship between GDP per capita and aggregated value indicator, 2010-2014

post-socialist countries are located in the bottom left corner. Countries with low levels of democracy, but relatively high levels of GDP per capita (Kuwait and Qatar) are located in the top left corner, while countries with relatively high levels of democracy, but low levels of GDP per capita (African and Asian countries) are located in the bottom right corner.

The last studied indicator is the level of economy openness that has been calculated as an average ratio between the level of trade (exports and imports of goods and services) and GDP over 2005-2009. We use data from the World Bank database ${ }^{5}$. The relationship between the level of trade and GDP per capita is very weak (Figure 13). African and South Asian countries have both low levels of GDP and low levels of openness. EU countries have both high levels of GDP and openness. However, many OECD countries have high level of GDP per capita, but relatively low level of openness. There are also countries with high level of openness, but relatively low level of GDP per capita - Ghana, Moldova, Jordan, and Thailand. Ukraine is located below the trend line, having average level of openness.

The relationship between GDP per capita and the level of trade became stronger for the new wave (Figure 14). Compared to the previous period, the highest trade growth was recorded in South Korea $(+20.3$ percentage points), Netherlands $(+18.8)$, and Romania (+17.2), while the highest decrease was recorded in Malaysia (-39.3), Egypt (-21.3), and Jordan $(-21.2)$. In Ukraine, the trade-to-GDP ratio grew by 7.6 percentage points. Low levels of GDP per capita and low levels of openness are observed in African and South Asian countries. The highest level of openness is observed in Singapore. The EU countries are generally characterized by the high levels of GDP per capita and relatively high levels of openness (Netherlands, Slovenia, and Estonia are among leaders). Australia, USA, and Japan demonstrate relatively low levels of openness, but high levels of GDP per capita. Malaysia, Belarus, Thailand, and Kyrgyzstan, despite relatively high levels of openness, are located below the trend line and have relatively low levels of GDP per capita.

Correlation analysis was used to establish the relationship between the level of welfare and the aggregate value indicator, the level of democracy and trade (openness) for two waves - 2005-2009 and 2010-2014. Correlation analysis confirms the previous results (Table 1). The relationships between GDP per capita and both the aggregated value indicator and the level of democracy are positive and significant, while

\footnotetext{
${ }^{5}$ World Development Indicators: Trade (\% of GDP). 2020. | Data. Available at: https://data.worldbank.org/indicator/NE.TRD.GNFS.ZS (accessed 30 April 2020)
} 


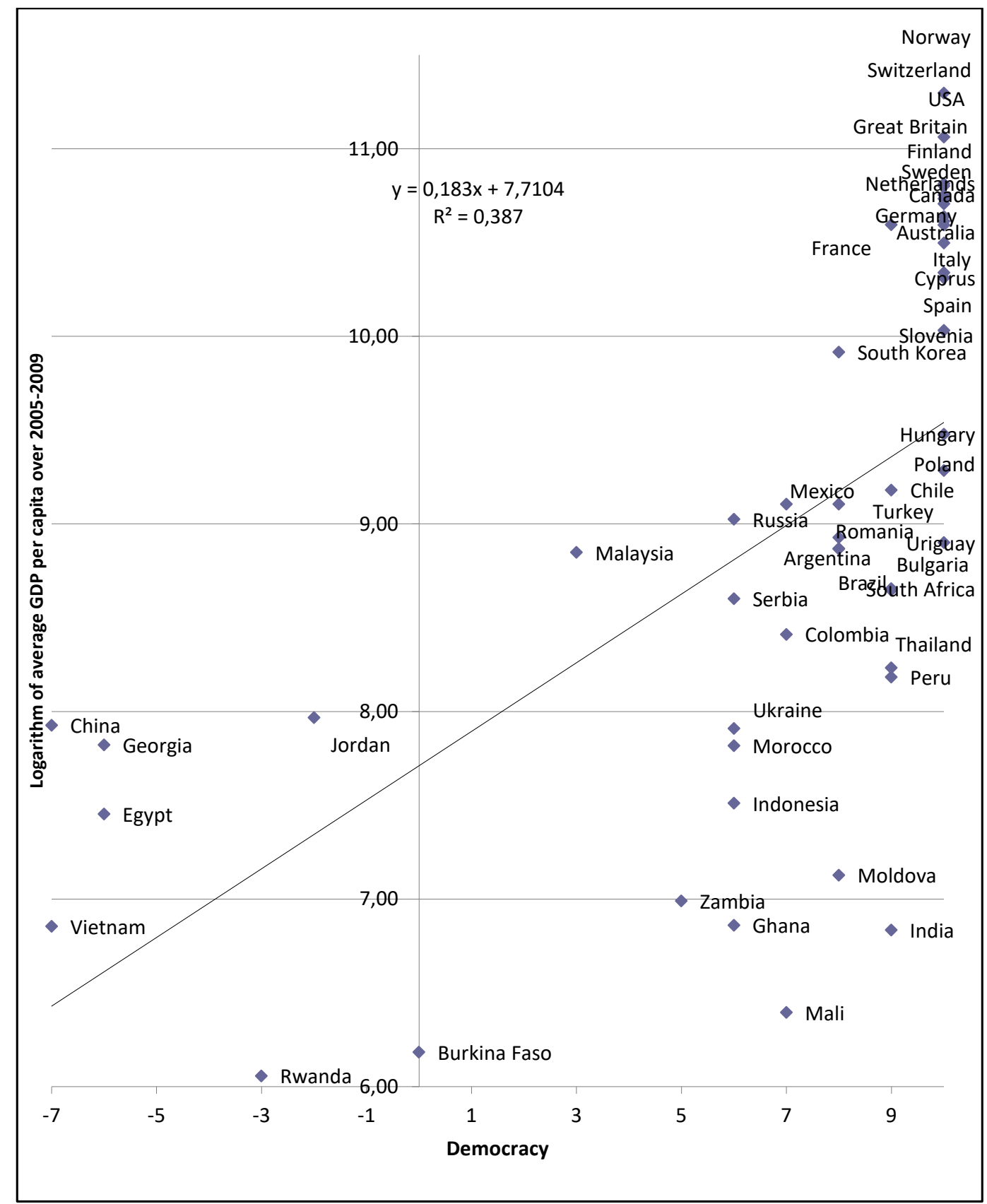

Figure 11. Relationship between GDP per capita and democracy, 2005-2009

the relationship between GDP per capita and trade is insignificant.

Compared to the previous period, the correlation coefficient between the level of democracy and GDP per capita became insignificant ( $p$-value $=0.22)$, and it is significantly different from the correlation coefficient for the previous period ( $p$-value = $0.0066)$. However, the significance of the correlation coefficient between GDP per capita and the level of trade improved (P-value 0.065 ). The correlation between GDP per capita and the aggregated value indicator remains relatively high and significant (Table 2).
The change in the coefficients for the last wave may be due to the fact that the sample for 2010-2014 increased by six countries which could affect the result. However, in two cases there is a very strong positive correlation between GDP per capita and aggregate value indicator, which once again confirms our hypothesis - values affect the level of welfare of the country and this can not be ignored.

Further, we conducted a regression analysis to find out how aggregated value indicator, the level of democracy and trade affect GDP per capita for two waves - 2005-2009 and 2010-2014 (Table 3 and 4). 


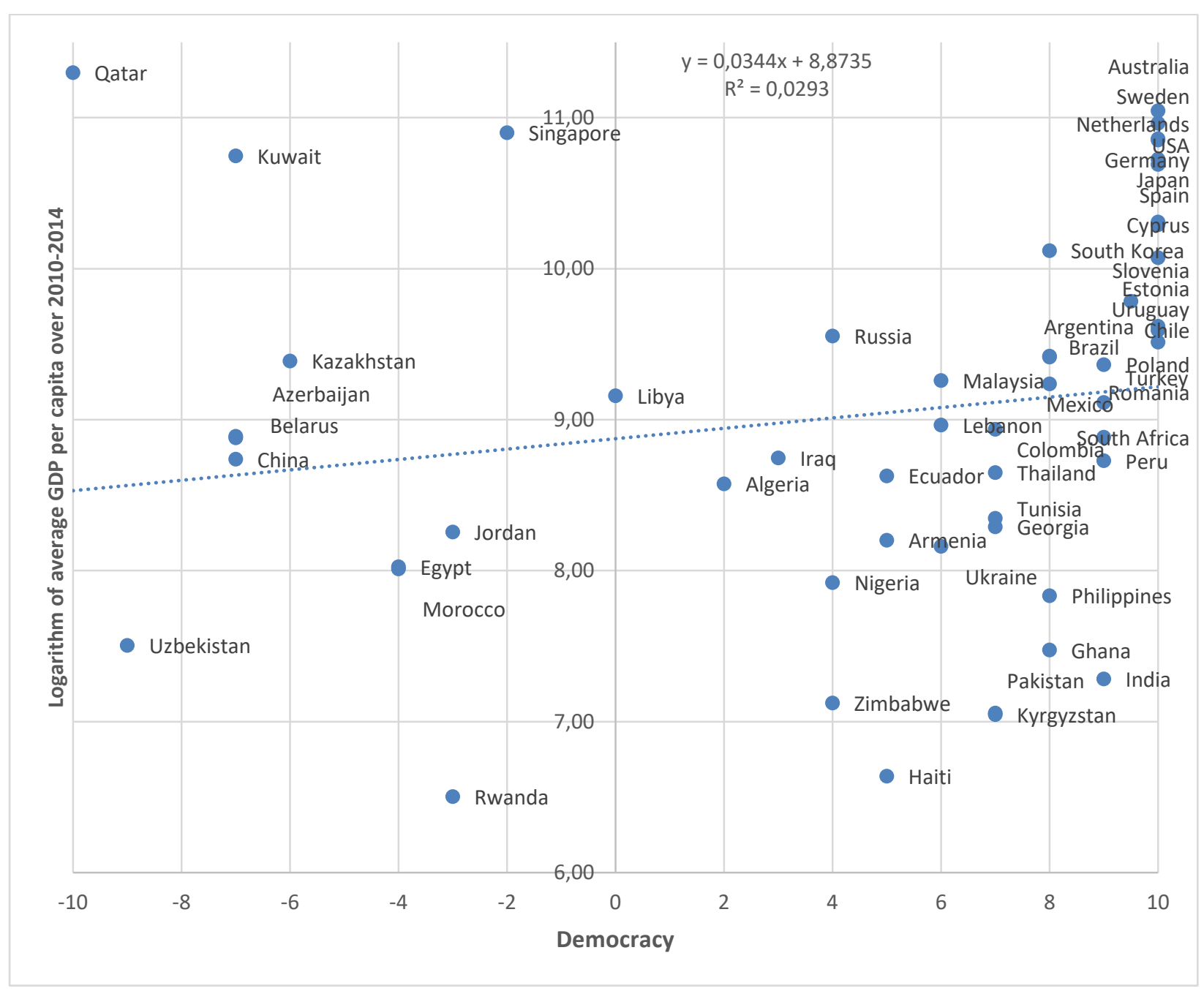

Figure 12. Relationship between GDP per capita and democracy, 2010-2014

Table 1

Correlation analysis of the relationship between GDP per capita and the aggregate value indicator, level of democracy and trade, 2005-2009

\begin{tabular}{|c|c|c|c|}
\hline & $\begin{array}{c}\text { Aggregated } \\
\text { value indicator }\end{array}$ & Trade & $\begin{array}{c}\text { Level of } \\
\text { democracy }\end{array}$ \\
\hline $\begin{array}{c}\text { Correlation with } \\
\text { GDP per capita }\end{array}$ & 0.775868 & 0.038677 & 0.622075 \\
\hline Observations & 48 & 48 & 48 \\
\hline P-value & $9.35 \mathrm{E}-11$ & 0.794094 & $2.36 \mathrm{E}-06$ \\
\hline
\end{tabular}

The equation to be estimated is:

$$
y=a+\beta_{1}{ }^{*} A V I+\beta_{2}{ }^{*} \mathrm{Dem}+\beta_{3}{ }^{*} \text { Trade, }
$$

where $y$ indicates Log (GDP per capita), AVI stands for values (informal institutions), Dem is a level of democracy and Trade is a level of openness.

As the sample of countries for the first wave is smaller, there are some limitations in the use of econometric instruments. Therefore, for this period, we obtained the result for the general sample, as well as separately
Table 2

Correlation analysis of the relationship between GDP per capita and the aggregate value indicator, level of democracy and trade, 2010-2014

\begin{tabular}{|c|c|c|c|}
\hline & $\begin{array}{c}\text { Aggregated } \\
\text { value indicator }\end{array}$ & Trade & $\begin{array}{c}\text { Level of } \\
\text { democracy }\end{array}$ \\
\hline $\begin{array}{c}\text { Correlation with GDP } \\
\text { per capita }\end{array}$ & 0.668724 & 0.252662 & 0.171194 \\
\hline Observations & 54 & 54 & 54 \\
\hline P-value (Correlation) & $3.27 \mathrm{E}-08$ & 0.06529 & 0.215814 \\
\hline $\begin{array}{c}\text { P-value (Compared } \\
\text { to the correlation f } \\
\text { or the previous wave) }\end{array}$ & 0.268153 & 0.283044 & 0.006608 \\
\hline
\end{tabular}

tested this hypothesis for countries where the level of democracy is high or above average. The results for 2005-2009 are represented in table 3.

Effects of the aggregated value indicator and the level of democracy are significant for the sample of all 48 countries and for the sample of 39 relatively democratic countries (index is higher than 5). 


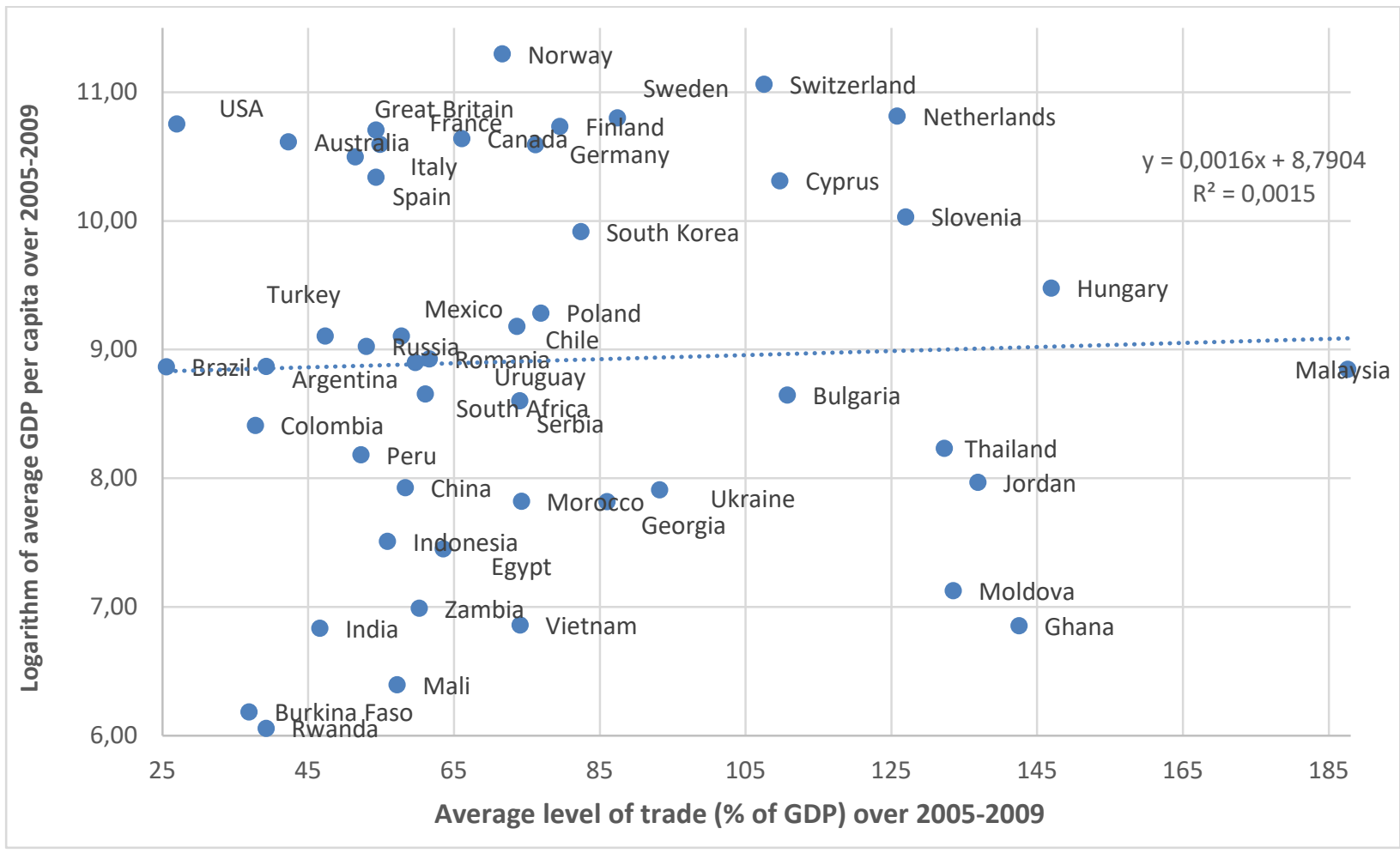

Figure 13. Relationship between GDP per capita and trade, 2005-2009

Moreover, the effect of the level of democracy is almost 4 times stronger for democratic countries, while the effect of the value indicator is stronger for the sample of all 48 countries. White Heteroskedasticity
Test provides no evidence of heteroskedasticity in all analyzed models.

Such an influence of democracy on the welfare of democratic countries may be due to the fact that

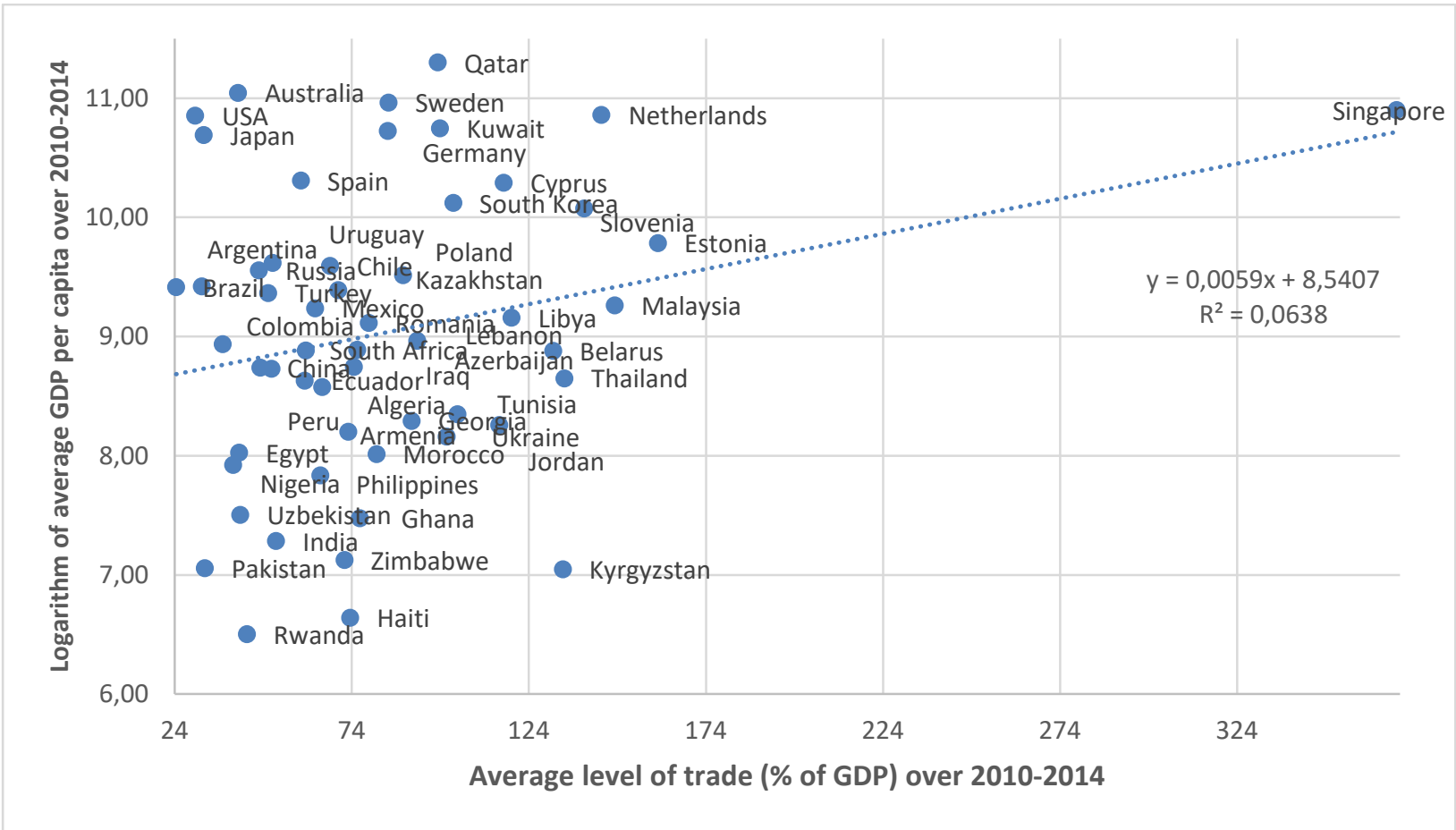

Figure 14. Relationship between GDP per capita and trade, 2010-2014 
Vol. 7 No. 2, 2021

Table 3

Regression analysis, 2005-2009

\begin{tabular}{|l|c|c|}
\hline \multicolumn{1}{|c|}{ Independent variables } & For all countries & $\begin{array}{c}\text { For democratic countries } \\
(\text { Level of democracy }>5)\end{array}$ \\
\hline Aggregated value indicator & $0.026215^{* * * *}$ & $0.018881^{* * *}$ \\
\hline Level of democracy & $0.101722^{* * *}$ & $0.382472^{* *}$ \\
\hline Trade & 0.001629 & -0.00191 \\
\hline R-squared & 0.696101 & 0.667452 \\
\hline Observations & 48 & 39 \\
\hline F-statistics (White Heteroskedasticity Test) & 0.381349 & 0.508194 \\
\hline
\end{tabular}

No stars means $\mathrm{P}>0.05, *$ means $\mathrm{P} \leq 0.05$, ** mean $\mathrm{P} \leq 0.01$, *** mean $\mathrm{P} \leq 0.001$, **** mean $\mathrm{P} \leq 0.0001$

democracy is a value itself and is formed under the influence of other values at the same time. It promotes effective interaction between government, business and society, which in turn increases the efficiency of production and redistribution, and thus contributes to institutional and economic development.

For the second wave (2010-2014), we tested our hypothesis for six samples: for all countries; democratic / non-democratic countries; high income / high and upper middle income / low, lower and middle income countries.

The results of the regression analysis (2010-2014) show a significant effect of the aggregated value indicator for all 6 samples (for non-democratic countries p-value is more than 0.05 but less than 0.1 ), but the effect is weaker for high income countries. The coefficient for the level of democracy for the new wave remains significant and positive only for the sub-sample of democratic countries, while it is negative for the high-income countries. The effect of the level of trade on GDP per capita is statistically significant for the sample of all countries, the sub-sample of non-democratic countries and the sub-sample of high income and upper-middle income countries (Table 4). White Heteroskedasticity Test provides no evidence of heteroskedasticity in all analysed models.

Therefore, depending on countries' democratic level, we have obtained an interesting result - the aggregate value indicator and the level of democracy are important factors of welfare in democratic countries. Instead, neither aggregate values nor democracy have an impact on GDP per capita in non-democratic countries. The level of welfare of these countries is affected by trade. This result is natural. Sustainable democracy and the values in democratic countries associated with it contribute to the growth of prosperity. In nondemocratic countries where the voice of society is weak, other factors have a greater influence.

\section{Conclusion}

In this paper we aim to explore how the social values (tolerance, obedience, trust, freedom of choice and control), democracy and trade can affect the level of welfare in different counties, since, there is uneven economic development in the world, which may be due to differences in social values that form the institutional environment. We hypothesize that the dominance in society of secular-rational values and the values of self-expression, democracy and trade (openness to the world) have a positive effect on the level of welfare of countries. Using correlation and regression analysis, the relationships between these indicators were evaluated.

As a consequence, the institutional factors (the values and the level of democracy) are important determinants of GDP per capita for democratic countries while for non-democratic countries trade is more important. There is a significant effect of the

Table 4

Regression analysis, 2010-2014

\begin{tabular}{|l|c|c|c|c|c|c|}
\hline \multicolumn{1}{|c|}{$\begin{array}{c}\text { Independent } \\
\text { variables }\end{array}$} & For all countries & $\begin{array}{c}\text { For democratic } \\
\text { countries (Level } \\
\text { of democracy>5) }\end{array}$ & $\begin{array}{c}\text { For non- } \\
\text { democratic } \\
\text { countries (Level } \\
\text { of democracy<6) }\end{array}$ & $\begin{array}{c}\text { For high-income } \\
\text { countries }\end{array}$ & $\begin{array}{c}\text { For high-income } \\
\text { and upper middle } \\
\text { income countries }\end{array}$ & $\begin{array}{c}\text { For low income, } \\
\text { lower and upper- } \\
\text { middle income } \\
\text { countries }\end{array}$ \\
\hline $\begin{array}{l}\text { Aggregated value } \\
\text { indicator }\end{array}$ & $0.031304^{* * * *}$ & $0.024772^{* * * *}$ & 0.026563 & $0.014276^{* *}$ & $0.02385^{* * * *}$ & $0.022993^{* * * *}$ \\
\hline Level of democracy & 0.028328 & $0.345843^{* *}$ & 0.013898 & $-0.04775^{*}$ & 0.010077 & 0.029608 \\
\hline Trade & $0.0063^{* *}$ & 0.002724 & $0.008803^{*}$ & 0.001029 & $0.00413^{*}$ & 0.000707 \\
\hline R-squared & 0.530667 & 0.677871 & 0.483579 & 0.561678 & 0.423934 & 0.29207 \\
\hline $\begin{array}{l}\text { Observations } \\
\text { F-statistics (White } \\
\text { Heteroskedasticity } \\
\text { Test) }\end{array}$ & 54 & 33 & 21 & 17 & 40 & 37 \\
\hline
\end{tabular}


aggregated value indicator for all countries, but this effect is weaker for high-income countries. The effect of the level of democracy is significant and positive only for the sub-sample of democratic countries, while it is negative for high-income countries. The effect of the level of trade on GDP per capita is statistically significant for the sample of all countries, the sub- sample of non-democratic countries and the subsample of high income and upper-middle income countries.

We have used a World Values Survey Dataset for two waves - 2005-2009 and 2010-2014 - which were collected from 48 countries for first wave and 54 countries for the second and World Bank Dataset.

\section{References:}

Amoranto, G., Chun, N., \& Deolalikar, A. (2010). Who are the Middle Class and What Values do They Hold? Evidence from the World Values Survey. Working Paper 229, Asian Development Bank. doi: 10.2139/ssrn.1743180

Dobler, C. (2011). The Impact of Formal and Informal Institutions on Economic Growth: A Case Study on the MENA Region, Hohenheimer volkswirtschaftliche Schriften, No. 65, ISBN 978-3-653-00883-8, Peter Lang International Academic Publishers, Frankfurt a. M. doi: 10.3726/978-3-653-00883-8

Inglehart, R., \& Welzel, C. (2005). Modernization, Cultural Change, and Democracy: The Human Development Sequence. Cambridge: Cambridge University Press. doi: 10.1017/CBO9780511790881

R., Inglehart, C. Haerpfer, A. Moreno, C. Welzel, K. Kizilova, J. Diez-Medrano, M. Lagos, P. Norris, E. Ponarin, \& B. Puranen et al. (eds.) (2014). World Values Survey: All Rounds - Country-Pooled Datafile Version: https://www.worldvaluessurvey.org/WVSDocumentationWVL.jsp. Madrid: JD Systems Institute.

Knowles, S., \& Weatherston, C. (2006). Informal institutions and cross-country income differences. Credit Research Paper, No. 06/06.

Polity IV Project: Political Regime Characteristics and Transitions, 1800-2007 (2020). Dataset User's Manual, Polity IV Project, Center for Global Policy, George Mason University, Polity IV data. Available at: https://www.systemicpeace.org/polity/polity4.htm (accessed 30 April 2020).

Pyrkosz, D. (2017). In Search for Cultural Determinants of Economic Development - the cases of Poland and Ukraine. Comparative Statistical Studies of the Development of Socio-Economic Systems. Proceedings of the XV International Scientific and Practical Conference on the Occasion of the Day of Statistics. Kyiv: Information and Analytical Agency, p. 99-105.

Tabellini, G. (2010). Culture and Institutions: Economic Development in the Regions of Europe. Journal of the European Economic Association, vol. 8(4), pp. 677-716. doi: 10.1111/j.1542-4774.2010.tb00537.x

Tabellini, G.(2005). Culture and Institutions: Economic Development in the Regions of Europe. CESifo Working Paper Series No. 1492, IGIER Working Paper No. 292. Available at: https://ssrn.com/abstract $=754086$

World Bank (2020). World Development Indicators (WDI) Online database, GDP Per Capita (Current US\$) | Data. Available at: https:// data.worldbank.org/indicator/NY.GDP.PCAP.CD (accessed 30 April 2020).

World Bank (2020). World Development Indicators (WDI) Online database, Trade (\% Of GDP)| Data. Available at: https://data.worldbank.org/indicator/NE.TRD.GNFS.ZS (accessed 30 April 2020).

WVS Database (2020). Worldvaluessurvey.us. Available at: http://worldvaluessurvey.us/WVSContents.jsp? CMSID=Findings (accessed 25 July 2020). 